\title{
Pemberian Sanksi Pelanggaran Pelaksanaan Jabatan Notaris Dan Perilaku Notaris Oleh Majelsi Pemeriksa
}

\author{
Eka Sulistya \\ Magister Kenotariatan Fakultas Hukum Universitas Islam Indonesia Yogyakarta Indonesia \\ Jln. Cik Di Tiro No. 1 Yogyakarta Indonesia \\ e_sulistya@yahoo.com
}

\begin{tabular}{ll}
\hline Key Word: & Abstract \\
Notary Function, & This study aims to analyze the existence of the Notary Supervisory Board in \\
Notary Supervision, & imposing sanctions for Notaries after the issuance of Ministry of Law and Human \\
sanctioning & Rights Regulation (Permenkumham) No. 15 of 2020 and the implementation of \\
& Permenkumham No. 15 of 2020. This is a normative juridical research, namely \\
& research whose main basis refers to secondary data consisting of primary, secondary \\
& and tertiary legal materials. The results of the study conclude that first, that the \\
& Regional Supervisory Council has the authority to impose sanctions on Notaries \\
& and Article 77 of the UUJN determines that the Central Supervisory Council has \\
& the authority to impose sanctions. However, in Article 1 point 4 of the \\
& Permenkumham No. 15 of 2020, it is stipulated that the authority to impose \\
& sanctions on Notaries lies with the Examining Council. Permenkumham No. 15 of \\
& 2020 contradicts the UUJN and since there are overlapping rules, the \\
& Permenkumham should not be able to downgrade or change the provisions in the \\
& UUJN. Second, the implementation of Article 1 point 4 of the Permenkumham No. \\
& 15 of 2020 on Procedures for Examination of the Supervisory Council Against \\
& Notaries is difficult to implement because the higher provisions, namely UUJN, does \\
& not regulate or authorize the Examining Council to impose sanctions on Notaries.
\end{tabular}

Kata-kata Kunci:
Jabatan Notaris,
Pengawasan
Notaris, Pemberian
Sanksi

Abstrak

Penelitian ini bertujuan untuk menganalisis keberadaan Majelis Pengawas Notaris dalam pemberian sanksi bagi Notaris pasca terbitnya Permenkumham Nomor 15 Tahun 2020 dan pelaksanaan Permenkumham Nomor 15 Tahun 2020. Penelitian ini adalah penelitian yuridis normatif, yaitu penelitian yang basis utamanya mengacu pada data sekunder yang terdiri dari bahan hukum primer, bahan hukum sekunder, dan bahan hukum tersier. Hasil penelitian menyimpulkan pertama, bahwa Majelis Pengawas Wilayah yang berwenang menjatuhkan sanksi kepada Notaris dan Pasal 77 UUJN menentukan pula Majelis Peng awas Pusat yang berwenang menjatuhkan sanksi. Namun dalam Pasal 1 angka 4 Permenkumham Nomor 15 Tahun 2020 tersebut menentukan bahwa kewenangan pemberian sanksi kepada Notaris ada pada Majelis Pemeriksa. Permenkumham Nomor 15 Tahun 2020 bertentangan dengan UUJN dan terkesan ada tumpang tindih aturan, semestinya Permenkumham tidak bisa men-downgrade atau mengubah ketentuan dalam UUJN. Kedua, pelaksanaan Pasal 1 angka 4 Permenkumham Nomor 15 Tahun 2020 tentang Tata Cara Pemeriksaan Majelis Pengawas Terhadap Notaris sulit diterapkan sebab berdasarkan ketentuan yang lebih tinggi, yakni UUJN tidak mengatur atau memberikan kewenangan terhadap Majelis Pemeriksa untuk memberikan sanksi terhadap Notaris 


\section{Pendahuluan}

Notaris dalam sektor pelayanan jasa adalah sebagai pejabat yang diberi wewenang oleh negara untuk melayani masyarakat dalam bidang perdata khususnya pembuatan akta otentik. Sebagaimana disebutkan dalam Pasal 1 angka 1 Undang-Undang Nomor 2 Tahun 2014 tentang Perubahan Atas Undang-Undang Nomor 30 Tahun 2004 tentang Jabatan Notaris (selanjutnya disebut UUJN), "Notaris adalah pejabat umum yang berwenang untuk membuat akta otentik dan memiliki kewenangan lainnya sebagaimana dimaksud dalam undang-undang ini atau berdasarkan undang-undang lainnya."

Kehadiran Notaris memegang peranan penting dalam lalu lintas hukum, khususnya yang berkaitan dengan pembuatan alat bukti tertulis yang bersifat otentik. Hal ini bertujuan untuk menjamin kepastian hukum, ketertiban, dan perlindungan hukum yang dibutuhkan masyarakat terkait alat bukti tertulis yang memiliki sifat otentik mengenai keadaan, peristiwa, atau perbuatan hukum, sebagaimana amanat pada pasal 1868 KUHPerdata yang berbunyi, "akta otentik adalah akta yang dalam bentuk yang ditentukan oleh undang-undang dibuat oleh atau di hadapan pejabat umum yang berwenang untuk itu di tempat dimana akta itu dibuat."1

Notaris dalam menjalankan tugas jabatannya sebagai pejabat umum yang berwenang membuat akta otentik diawasi oleh Majelis Pengawas Notaris yang dibentuk oleh Menteri. Ketentuan mengenai pengawasan terhadap Notaris diatur dalam UUJN Bab IX tentang Pengawasan. Lebih lanjut, berdasarkan Pasal 1 angka 5 Peraturan Menteri Hukum dan Hak Asasi Manusia Republik Indonesia Nomor: M.02.PR.08.10 Tahun 2004 tentang Tata Cara Pengangkatan Anggota, Pemberhentian Anggota Susunan Organisasi, Tata Cara Kerja dan Tata Cata Pemeriksaan Majelis Pengawas Notaris (selanjutnya disebut Permenkumham 02/2004) menjelaskan mengenai pengertian dari pengawasan yang berbunyi sebagai berikut, "pengawasan adalah kegiatan yang bersifat preventif dan kuratif termasuk kegiatan pembinaan yang dilakukan oleh Majelis Pengawas terhadap Notaris."2

Tujuan dari pengawasan yang dilakukan terhadap Notaris ialah agar Notaris dalam melaksanakan tugas jabatannya dapat memenuhi persyaratan-persyaratan yang dituntut kepadanya. Persyaratan-persyaratan yang dituntut tersebut tidak hanya mencakup hal-hal yang dituntutkan oleh hukum atau undang-undang saja, melainkan juga berdasarkan kepercayaan yang diberikan oleh klien terhadap Notaris tersebut. ${ }^{3}$ Berdasarkan Pasal 73 ayat (1) huruf a UUJNP dan Pasal 77 huruf a UUJNP menentukan bahwa Majelis Pengawas Wilayah (MPW) dan Majelis Pengawas Pusat (MPP) adalah suatu badan yang bewenang menjatuhkan sanksi terhadap Notaris yang melanggar ketentuan UUJN. Bahwasannya Majelis Pengawas Notaris merupakan perpanjangantangan Menteri terkait dengan pengawasan terhadap Notaris. Namun di dalam ketentuan Pasal 1 angka 4 Peraturan Menteri Hukum dan Hak Asasi Manusia Republik Indonesia Nomor 15 Tahun 2020 tentang

${ }^{1}$ R. Subekti dan R. Tjitrosudibio, Kitab Undang-Undang Hukum Perdata, PT. Pradnya Paramita, Jakarta, 2009, hlm. 475.

${ }^{2}$ Lihat dalam Pasal 1 angka 5 Permenkumham Nomor M.02.PR.08.10 Tahun 2004 tentang tentang Tata Cara Pengangkatan Anggota, Pemberhentian Anggota Susunan Organisasi, Tata Cara Kerja dan Tata Cata Pemeriksaan Majelis Pengawas Notaris.

${ }^{3}$ Lihat dalam Pasal 67 ayat (1) huruf a Undang-Undang Nomor 2 Tahun 2014 tentang Perubahan Atas Undang-Undang Nomor 30 Tahun 2004 tentang Jabatan Notaris. 
Tata Cara Pemeriksaan Majelis Pengawas Terhadap Notaris (selanjutnya disebut Permenkumham No. 15/2020) menyebutkan, “Majelis Pemeriksa adalah tim pemeriksa yang memiliki wewenang melakukan pemeriksaan dan penjatuhan sanksi yang dibentuk oleh Majelis Pengawas Notaris". Kemudian, Pasal 36 ayat (1) Permenkumham No. 15/2020 juga disebutkan bahwa, "dalam hal Notaris terbukti melakukan pelanggaran perilaku dan pelaksanaan jabatan, Majelis Pemeriksa menjatuhkan sanksi."

Berdasarkan uraian tersebut, Penulis melihat bahwa ada tumpang tindih kewenangan antara Majelis Pengawas Wilayah dan Majelis Pusat dengan Majelis Pemeriksa dalam memberikan sanksi bagi Notaris yang terbukti telah melakukan pelanggaran ketentuan Undang-Undang Jabatan Notaris. Oleh sebab itu, Penulis tertarik untuk meneliti tentang "Sanksi Pelanggaran Pelaksanaan Jabatan Notaris Dan Perilaku Notaris Setelah Berlakunya Peraturan Menteri Hukum Dan Hak Asasi Manusia Republik Indonesia Nomor 15 Tahun 2020 Tentang Tata Cara Pemeriksaan Majelis Pengawas Terhadap Notaris."

\section{Rumusan Masalah}

Adapun yang menjadi rumusan masalah dalam penelitian ini yang pertama, bagaimana keberadaan Majelis Pengawas Notaris dalam pemberian sanksi bagi Notaris pasca terbitnya Permenkumham Nomor 15 Tahun 2020 tentang Tata Cara Pemeriksaan Majelis Pengawas Terhadap Notaris? Kedua, bagaimanakah pelaksanaan Permenkumham Nomor 15 Tahun 2020 Nomor 15 Tahun 2020 tentang Tata Cara Pemeriksaan Majelis Pengawas Terhadap Notaris?

\section{Tujuan Penelitian}

Tujuan yang hendak dicapai melalui penelitian ini adalah pertama, menganalisis keberadaan Majelis Pengawas Notaris dalam pemberian sanksi bagi Notaris pasca terbitnya Permenkumham Nomor 15 Tahun 2020 tentang Tata Cara Pemeriksaan Majelis Pengawas Terhadap Notaris. Kedua, menganalisis pelaksanaan Permenkumham Nomor 15 Tahun 2020 tentang Tata Cara Pemeriksaan Majelis Pengawas Terhadap Notaris.

\section{Metode Penelitian}

Penelitian ini adalah penelitian yuridis normatif, yaitu basis utamanya mengacu pada data sekunder yang terdiri dari bahan hukum primer, bahan hukum sekunder, dan bahan hukum tersier. Untuk melengkapi penelitian ini juga didukung oleh data primer, seperti wawancara dengan narasumber-narasumber terkait dengan tema penelitian.

\section{Hasil Penelitian dan Pembahasan}

Keberadaan Majelis Pengawas Notaris dalam Pemberian Sanksi bagi Notaris Pasca Terbitnya Peraturan Menteri Hukum dan Hak Asasi Manusia Republik Indonesia Nomor 15 Tahun 2020 tentang Tata Cara Pemeriksaan Majelis Pengawas Terhadap Notaris

Lembaga pengawas jabatan dan profesi Notaris diwajibkan untuk dapat menjalankan fungsi pengawasan dan pembinaan secara optimal, demi menjamin 
terciptanya kepastian, ketertiban, dan perlindungan hukum bagi masyarakat sebagai pengguna jasa Notaris. Sehingga Notaris dalam melaksanakan tugas jabatannya wajib berpegang dan berdasarkan peraturan perundang-undangan yang mengatur jabatan. Selain patuh dan taat terhadap UUJN, Notaris juga wajib mentaati dan patuh terhadap aturan-aturan yang tertuang dalam kode etik Notaris. Kode etik Notaris diharapkan dapat menuntun Notaris untuk dapat menjaga keluhuran dan martabat jabatan Notaris.

Bagi Notaris yang melakukan pelanggaran Kode Etik, Dewan Kehormatan berkoordinasi dengan Majelis Pengawas berwenang melakukan pemeriksaan atas pelanggaran tersebut dan dapat menjatuhkan sanksi kepada pelanggarnya, sanksi yang dikenakan terhadap anggota Ikatan Notaris Indonesia (INI), yang melakukan pelanggaran Kode Etik dapat berupa teguran, peringatan, schorsing (pemecatan sementara) dari keanggotaan perkumpulan, onzetting (pemecatan) dari keanggotaan perkumpulan, pemberhentian dengan hormat hingga secara tidak hormat dari keanggotaan perkumpulan. Adapun penjatuhan sanksi-sanksi sebagaimana terurai di atas terhadap anggota yang melanggar Kode Etik disesuaikan dengan kuantitas dan kualitas pelanggaran yang dilakukan anggota tersebut.

Posisi Dewan Kehormatan sangat strategis karena dipundaknya tersemat amanat untuk memastikan para Notaris memahami dan melaksanakan kode etik secara konsisten baik dan benar. Dewan Kehormatan juga ikut memberikan kontribusi kepada eksistensi, kehormatan, dan keluhuran profesi jabatan Notaris di tengah masyarakat. Sebelum diberlakukannya UUJN dan juga sebagaimana yang terdapat dalam Peraturan Jabatan Notaris di Indonesia 1860 Nomor 3 (Reglement op het Notaris-ambt in Indonesie), pengawasan dan penjatuhan sanksi dilakukan oleh pengadilan negeri yang pada waktu itu diatur dalam Pasal 50 Reglement op het Notaris-ambt in Indonesie. Seorang Notaris yang melakukan perbuatan dengan mengabaikan keluhuran martabat atau tugas jabatannya, melanggar peraturan umum atau melakukan kesalahan-kesalahan lain, baik di dalam maupun di luar lingkup jabatannya sebagai Notaris, hal itu akan dilaporkan kepada pengadilan negeri oleh penuntut umum yang di daerah hukumnya terletak tempat kedudukan Notaris itu.

Seiring perkembangan hukum Notariat, maka pengawasan oleh Notaris dilakukan oleh Mahkamah Agung dan peradilan umum sebagaimana tersebut dalam Pasal 32 dan 54 Undang-Undang Nomor 13 Tahun 1965 tentang Pengadilan dalam Lingkup Peradilan Umum dan Mahkamah Agung. Kemudian dibuat pula Surat Edaran Mahkamah Agung Republik Indonesia Nomor 2 Tahun 1984 tentang Tata Cara Pengawasan Terhadap Notaris, Keputusan Bersama Ketua Mahkamah Agung dan Menteri Kehakiman Nomor KMA/006/SKB/VII/1987 tentang Tata Cara Pengawasan, Penindakan, dan Pembelaan Diri Notaris, dan terakhir dalam Pasal 54 Undang-Undang Nomor 8 Tahun 2004 tentang Perubahan Atas Undang-Undang Nomor 14 Tahun 1985 tentang Mahkamah Agung. Lebih lanjut P. Nicolai berpendapat, tujuan pengawasan merupakan langkah preventif untuk memaksakan kepatuhan. ${ }^{4}$

Reformasi birokrasi setelah ada di lingkungan Mahkamah Agung dan berdasarkan aturan tersebut, maka Mahkamah Agung hanya mempunyai kewenangan dalam 
lingkup peradilan saja. Maka sejak diadakannya pembatasan terhadap kewenangan Mahkamah Agung tersebut, kemudian pengawasan terhadap Notaris yang semula diatur dalam Pasal 54 Undang-Undang Nomor 8 Tahun 2004 dicabut melalui Pasal 91 UndangUndang 30 Tahun 2004 tentang Jabatan Notaris, sehingga kewenangan untuk melakukan pengawasan, pemeriksaan, penjatuhan sanksi, dan pembinaan terhadap Notaris dilakukan oleh Menteri Hukum dan Hak Asasi Manusia dengan cara membentuk Majelis Pengawas Notaris. ${ }^{5}$

Pasca pemberlakuan UUJN, yang mempunyai wewenang ${ }^{6}$ melakukan pengawasan dan pemeriksaan terhadap Notaris adalah Menteri Hukum dan Hak Asasi Manusia Republik Indonesia yang dalam pelaksanaannya Menteri membentuk dan mendelegasikan kewenangan pengawasan terhadap notaris kepada Majelis Pengawas Notaris. Pasal (1) angka 6 UUJN menetapkan bahwa Majelis Pengawas Notaris adalah suatu badan yang mempunyai kewenangan dan kewajiban untuk melaksanakan pembinaan dan pengawasan terhadap Notaris. Majelis Pengawas Notaris adalah suatu lembaga yang mempunyai kewenangan dan kewajiban untuk melakukan pembinaan dan pengawasan terhadap Notaris. Notaris sebagai pejabat umum merupakan sekelompok figur masyarakat yang mempunyai kualifikasi berupa keahlian hukum tertentu, yang tidak dimiliki oleh anggota masyarakat lain. Sebagai kumpulan masyarakat yang mempunyai keahlian tertentu, kelompok masyarakat ini dapat memberikan kontribusi kemajuan dan manfaat positif bagi masyarakat. Tetapi sebaliknya, hal ini dapat juga menjadikan penyalahgunaan keahlian sehingga dapat menimbulkan kerugian bagi masyarakat. Oleh karena itu untuk mengantisipasi hal tersebut diperlukan pengaturan yang komprehensif terhadap Notaris baik mengenai syarat dan tata cara pengangkatan, perpindahan dan pemberhentian Notaris maupun mengenai pembinaan dan pengawasan terhadap perilaku Notaris dan pelaksanaan jabatan Notaris. Majelis Pengawas terdiri atas unsur pemerintah, organisasi Notaris dan akademisi masing-masing sebanyak 3 orang.

Majelis Pengawas Notaris sebagai satu-satunya institusi/lembaga yang berwenang melakukan pengawasan, pemeriksaan dan menjatuhkan sanksi terhadap Notaris, tiap jenjang Majelis Pengawas (MPD, MPW, dan MPP) mempunyai wewenang masingmasing, yaitu: ${ }^{7}$

\section{Majelis Pengawas Daerah}

Majelis Pengawas daerah dibentuk di kabupaten atau kota yang mana ketua dan wakilnya dipilih dari dan oleh anggotanya. Masa jabatan ketua, wakil ketua, dan anggota

${ }^{5}$ Muhammad Luthfan Hadi Darus, Op. Cit., hlm. 116.

${ }^{6}$ Pernyataan ini mengadopsi pendapat Philipus M. Hadjon, bahwa istilah wewenang atau kewenangan yang disejajarkan dengan istilah bevoegdheid dalam konsep hukum publik. Sebagai suatu konsep hukum publik, wewenang atas (sekurang-kurangnya) tiga komponen, yaitu (1) pengaruh, bahwa penggunaan wewenang dimaksudkan untuk mengendalikan perilaku subjek hukum; (2) dasar hukum, bahwa wewenang itu selalu harus dapat ditunjuk dasar hukumnya; dan (3) konformitas hukum, bahwa mengandung makna adanya standar wewenang, yaitu standar umum (semua jenis wewenang), dan standar khusus (untuk jenis tertentu). Philipus M. Hadjon, "Tentang Wewenang Pemerintahan (Bestuursbevoegdheid)", Pro Justicia, Fakultas Hukum Universitas Parahyangan Bandung, Tahun XVI Nomor 1, Januari 1998, hlm. 2.

${ }^{7}$ Habib Adjie, Majelis Pengawas Notaris sebagai Pejabat Tata Usaha Negara, Cetakan Kesatu, Refika Aditama, Bandung, 2011, hlm. 6. 
Majelis Pengawas Daerah adalah 3 (tiga) tahun dan dapat diangkat kembali, MPD dibantu oleh seorang sekretaris atau lebih yang ditunjuk dalam rapat MPD. Sebelum dikeluarkannya UUJNP, wewenang MPD diatur dalam UUJN, Permenkumham Nomor 02/2004, dan Keputusan Menteri Hukum dan HAM Republik Indonesia Nomor M.39PW.07.10. Tahun 2004. Dalam kaitan ini MPD harus objektif ketika melakukan pemeriksaan atau meminta keterangan dari Notaris untuk memenuhi permintaan peradilan, penyidik, penuntut umum atau hakim. Tanpa ada izin dari MPD penyidik, penuntut umum dan hakim tidak dapat memanggil atau meminta Notaris dalam suatu perkara pidana. ${ }^{8}$ Pasal 70 UUJN mengatur wewenang MPD yang berkaitan dengan:

a. Menyelenggarakan sidang untuk memeriksa adanya dugaan pelanggaran Kode Etik Notaris atau pelanggaran pelaksanaan jabatan Notaris;

b. Melakukan pemeriksaan terhadap Protokol Notaris secara berkala 1(satu) kali dalam 1 (satu) tahun atau setiap waktu yang dianggap perlu;

c. Memberikan izin cuti untuk waktu sampai dengan 6 (enam) bulan;

d. Menetapkan Notaris Pengganti dengan memperhatikan usul Notaris yang bersangkutan;

e. Menentukan tempat penyimpanan Protokol Notaris yang pada saat serah terima Protokol Notaris telah berumur 25 (dua puluh lima) tahun atau lebih;

f. Menunjuk Notaris yang akan bertindak sebagai pemegang sementara Protokol Notaris yang diangkat sebagai pejabat negara sebagaimana dimaksud dalam Pasal 11 ayat (4);

g. Menerima laporan dari masyarakat mengenai adanya dugaan pelanggaran Kode Etik Notaris atau pelanggaran ketentuan dalamUndang-Undang ini; dan

h. Membuat dan menyampaikan laporan sebagaimana dimaksud pada huruf a, huruf $b$, huruf $c$, huruf d, huruf e, huruf f, dan huruf g kepada Majelis Pengawas Wilayah.

\section{Majelis Pengawas Wilayah}

Majelis Pengawas Wilayah dibentuk dan berkedudukan di Ibu Kota Provinsi yang mana ketua dan wakilnya dipilih dari dan oleh anggotanya. Masa jabatan ketua, wakil ketua, dan anggota Majelis Pengawas Wilayah adalah 3 (tiga) tahun dan dapat diangkat kembali, MPW dibantu oleh seorang sekretaris atau lebih yang ditunjuk dalam rapat MPW. Wewenang MPW di samping diatur dalam UUJN, juga diatur dalam Permenkumham Nomor 02/2004 dan Keputusan Menteri Hukum dan Hak Asasi Manusia Republik Indonesia Nomor M.39-PW.07.10. Tahun 2004. Menurut Pasal 73 ayat (2) UUJN, Keputusan MPW sebagaimana yang dimaksud pada ayat (1) hurf e bersifat final, dan terhadap setiap keputusan penjatuhan sanksi sebagaimana dimaksud pada ayat (1) huruf e dan huruf $f$ dibuatkan berita acara (Pasal 73 ayat (3) UUJN). Wewenang MPW menurut Pasal 26 Permenkumham Nomor 02/2004, berkaitan dengan pemeriksaan yang dilakukan oleh MPW, yaitu:

a. Majelis Pemeriksa Wilayah memeriksa dan memutus hasil pemeriksaan Majelis Pemeriksa Daerah; 
b. Majelis Pemeriksa Wilayah mulai melakukan pemeriksaan terhadap hasil pemeriksaan Majelis Pengawas Daerah dalam jangka waktu paling lambat 7 (tujuh) hari kalender sejak berkas diterima;

c. Majelis Pemeriksa Wilayah berwenang memanggil pelapor dan terlapor untuk didengar keterangannya;

d. Putusan diucapkan dalam jangka waktu paling lambat 30 (tiga puluh) hari kalender sejak berkas diterima.

Dalam angka 2 butir 1 Keputusan Menteri Hukum dan Hak Asasi Manusia Republik Indonesia Nomor M.39-PW.07.10.Tahun 2004, mengenai Tugas Majelis Pengawas menegaskan bahwa MPW berwenang untuk menjatuhkan sanksi yang tersebut dalam Pasal 73, 85 UUJN, dan Pasal 26 Permenkumham Nomor 02/2004, kemudian angka 2 butir 2 Keputusan Menteri Hukum dan Hak Asasi Manusia Republik Indonesia Nomor M.39-PW.07.10.Tahun 2004 mengatur pula mengenai kewenangan MPW, yaitu:

a. Mengusulkan kepada Majelis Pengawas Pusat pemberian sanksi pemberhentian dengan hormat;

b. Memeriksa dan memutus keberatan atas putusan penolakan cuti oleh Majelis Pengawas Daerah;

c. Mencatat izin cuti yang diberikan dalam setifikat cuti;

d. Melaporkan kepada instansi yang berwenang adanya dugaan unsur pidana yang diberitahukan oleh Majelis Pengawas Daerah. Atas laporan tersebut, setelah dilakukan pemeriksaan oleh Majelis Pemeriksa Wilayah hasilnya disampaikan kepada Majelis Pengawas Pusat;

e. Menyampaikan laporan kepada Majelis Pengawas Pusat.

\section{Majelis Pengawas Pusat}

Majelis Pengawas Pusat dibentuk dan berkedudukan di Ibu Kota Negara yang mana ketua dan wakilnya dipilih dari dan oleh anggotanya. Masa jabatan ketua, wakil ketua, dan anggota Majelis Pengawas Pusat adalah 3 tahun dan dapat diangkat kembali, MPP dibantu oleh seorang sekretaris atau lebih yang ditunjuk dalam rapat MPP. Wewenang MPP di samping diatur dalam UUJN, juga diatur dalam Permenkumham Nomor 02/2004, dan Keputusan Menteri Hukum dan Hak Asasi Manusia Republik Indonesia Nomor M.39-PW.07.10.Tahun 2004. Dalam Pasal 77 UUJN diatur mengenai wewenang MPP yang berkaitan dengan:

a. Menyelenggarakan sidang untuk memeriksa dan mengambil keputusan dalam tingkat banding terhadap penjatuhan sanksi dan penolakan cuti;

b. Memanggil Notaris terlapor untuk dilakukan pemeriksaan sebagaimana dimaksud pada huruf a;

c. Menjatuhkan sanksi pemberhentian sementara;

d. Mengusulkan pemberian sanksi berupa pemberhentian dengan tidak hormat kepada Menteri.

Selanjutnya wewenang MPP diatur juga dalam Pasal 29 Permenkumham Nomor 02/2004, yang berkaitan dengan pemeriksaan lebih lanjut yang diterima dari MPW:

1) Majelis Pemeriksa Pusat memeriksa permohonan banding atas putusan Majelis Pemeriksa Wilayah; 
2) Majelis Pemeriksa Pusat mulai melakukan pemeriksaan terhadap berkas permohonan banding dalam jangka waktu paling lambat 7 (tujuh) hari kalender sejak berkas diterima;

3) Majelis Pemeriksa Pusat berwenang memanggil pelapor dan terlapor untuk dilakukan pemeriksaan guna didengar keterangannya.

4) Putusan diucapkan dalam jangka waktu paling lambat 30 (tiga puluh) hari kalender sejak berkas diterima;

5) Putusan sebagaimana dimaksud pada ayat (2) harus memuat alasan dan pertimbangan yang cukup, yang dijadikan dasar untuk menjatuhkan putusan;

6) Putusan sebagaimana dimaksud pada ayat (4) ditandatangani oleh Ketua, Anggota, dan Sekretaris Majelis Pemeriksa Pusat;

7) Putusan Majelis Pemeriksa Pusat disampaikan kepada Menteri, dan salinannya disampaikan kepada pelapor, terlapor, Majelis Pengawas Daerah, Majelis Pengawas Wilayah, Pengurus Pusat Ikatan Notaris Indonesia, dalam jangka waktu paling lambat 30 (tiga puluh) hari kalender terhitung sejak putusan diucapkan.

Dalam angka 3 butir 1 Keputusan Menteri Hukum dan Hak Asasi Manusia Republik Indonesia Nomor M.39-PW.07.10. Tahun 2004, mengenai Tugas Majelis Pengawas, bahwa MPP berwenang untuk melaksanakan ketentuan yang tersebut dalam Pasal 77, Pasal 84 UUJN dan 85 UUJN, dan wewenang lain, yaitu:

1) Memberikan izin cuti lebih dari 1 (satu) tahun dan mencatat izin cuti dalam sertifikat cuti;

2) Mengusulkan kepada Menteri pemberian sanksi pemberhentian sementara;

3) Mengusulkan kepada Menteri pemberian sanksi pemberhentian dengan hormat;

4) Menyelenggarakan sidang untuk memeriksa dan mengambil putusan dalam tingkat banding terhadap penjatuhan sanksi, kecuali sanksi berupa terguran lisan dan tertulis;

5) Menyelenggarakan sidang untuk memeriksa dan mengambil putusan dalam tingkat banding terhadap penolakan cuti dan putusan tersebut bersifat final.

Mengenai kewenangan Majelis Pengawas (Daerah, Wilayah dan Pusat) ini, terdapat satu kewenangan Majelis Pengawas yang perlu untuk diluruskan sesuai aturan hukum yang berlaku, yaitu atas laporan Majelis Pemeriksa jika menemukan suatu tindak pidana dalam melakukan pemeriksaan terhadap Notaris, maka Majelis Pengawas akan melaporkannya kepada pihak yang berwenang. Substansi pasal ini telah menempatkan Majelis Pengawas Notaris sebagai pelapor tindak pidana. ${ }^{9}$

Saat ini, pemerintah dalam hal ini Kementerian Hukum dan Hak Asasi Manusia Republik Indonesia (Kemenkumham RI) telah menerbitkan aturan baru mengenai pengawasan Notaris, yakni Peraturan Menteri Hukum dan Hak Asasi Manusia Republik Indonesia Nomor 15 Tahun 2020 tentang Tata Cara Pemeriksaan Majelis Pengawas Terhadap Notaris. Dalam ketentuan tersebut, pengaturan tentang pemberian sanksi terhadap Notaris dilakukan oleh Majelis Pemeriksa. Apabila kita merujuk pada ketentuan-ketentuan yang telah disebutkan di atas, yakni Pasal 20 ayat (1) dan ayat (2) Permenkumham Nomor 02/2004 menyatakan bahwa: 
(1)Dalam melakukan pemeriksaan terhadap Notaris, Ketua Majelis Pengawas Notaris membentuk Majelis Pemeriksa Daerah, Majelis Pemeriksa Wilayah, dan Majelis Pemeriksa Pusat dari masing-masing unsur yang terdiri atas 1 (satu) orang ketua dan 2 (dua) orang anggota Majelis Pemeriksa;

(2) Majelis Pemeriksa Wilayah dan Majelis Pemeriksa Pusat berwenang memeriksa dan memutus laporan yang diterima.

Keberadaan Majelis Pemeriksa merupakan tim yang dibentuk oleh Majelis Pengawas Daerah (MPD). Majelis Pemeriksa berwenang untuk melakukan pemeriksaan terhadap Notaris yang dilaporkan, kemudian memberikan laporan ke MPD. Kemudian MPD membuat laporan untuk kemudian diteruskan kepada MPW. Selanjutnya, MPW akan memeriksa Notaris yang bersangkutan (dengan membentuk Majelis Pemeriksa di tingkat wilayah), jika terbukti maka MPW akan menjatuhkan sanksi. Jika Notaris tidak setuju atau melakukan banding dengan keputusan MPW, maka Notaris yang bersangkutan bisa mengajukan keberatan ke MPP (dengan membentuk Majelis Pemeriksa di tingkat pusat), dan kemudian yang berwenang menjatuhkan sanksi yaitu MPW atau MPP.

Padahal, apabila merujuk pada ketentuan Pasal 73 UUJN ditentukan bahwa MPW yang berwenang menjatuhkan sanksi kepada Notaris dan Pasal 77 UUJN menentukan pula MPP yang berwenang menjatuhkan sanksi. Namun dalam Permenkumham Nomor 15 Tahun 2020 tersebut menentukan bahwa kewenangan pemberian sanksi kepada Notaris ada pada Majelis Pemeriksa (Pasal 1 angka 4). Permenkumham Nomor 15 Tahun 2020 bertentangan dengan UUJN, dan perlu bagi organisasi Notaris untuk menyampaikan hal tersebut ke KeMenterian Hukum dan Hak Asasi Manusia Republik Indonesia.

Kemudian, menurut Ni'matul Huda bahwa kedudukan Permenkumham jauh di bawah UUJN, sehingga substansinya tidak boleh bertentangan dengan UUJN. Majelis Pengawas Notaris kedudukan serta wewenangnya tetap mengacu pada ketentuan UUJN. Dimana kewenangan dalam pemberian sanksi terhadap Notaris ada pada Majelis Pengawas Notaris seperti ketentuan Pasal 73 ayat (1) huruf a UUJNP menyebutkan bahwa, Majelis Pengawas Wilayah berwenang menyelenggarakan sidang untuk memeriksa dan mengambil keputusan atas laporan masyarakat yang disampaikan melalui MPW dan Pasal 77 UUJNP, “Majelis Pengawas Pusat berwenang menyelenggarakan sidang untuk memeriksa dan mengambil keputusan dalam tingkat banding terhadap penjatuhan sanksi dan penolakan cuti. ${ }^{10}$ Dalam hal pemberian sanksi bagi Notaris seharusnya hanya Majelis Pengawas Notaris saja yang diberikan kewenangan, demi terciptanya suatu kepastian hukum terhadap pengawasan Notaris.

\section{Pelaksanaan Peraturan Menteri Hukum dan Hak Asasi Manusia Republik Indonesia Nomor 15 Tahun 2020 tentang Tata Cara Pemeriksaan Majelis Pengawas Terhadap Notaris}

Negara Indonesia adalah negara hukum, pernyataan tersebut diatur di dalam Undang-Undang Dasar Negara Republik Indonesia 1945, Pasal 1 ayat (3) yang

${ }^{10}$ Hasil wawancara dengan Ni'matul Huda, Guru Besar Hukum Tata Negara Fakultas Hukum Universitas Islam Indonesia, 20 November 2020. 
dirumuskan dalam amandemennya yang ketiga tanggal 10 November 2001.11 Sebagai konsekuensi dari paham berbangsa dan bernegara harus berdasarkan pada ketentuan hukum dan tidak boleh menyimpang pada norma-norma hukum yang berlaku di Indonesia.

Dalam menjalankan tugas jabatannya, Notaris juga wajib untuk taat pada ketentuan hukum yang menaungi pelaksanaan jabatannya. Selain kewajiban untuk mentaati ketentuan-ketenntuan hukum yang ada, Notaris juga diawasi oleh lembagalembaga pengawas yang memiliki tupoksi tugas masing-masing. Tujuan dari pengawasan itu sendiri agar para Notaris ketika menjalankan tugas jabatannya memenuhi persyaratan yang berkaitan dengan pelaksanaan tugas jabatan Notaris demi untuk pengamanan kepentingan masyarakat, karena Notaris diangkat oleh pemerintah bukan untuk kepentingan Notaris sendiri tetapi untuk kepentingan masyarakat yang dilayaninya. ${ }^{12}$

Adapun langkah-langkah hukum secara kongkrit yang dapat dilakukan oleh Majelis Pengawas Notaris untuk melakukan pengawasan, yaitu dengan melakukan berbagai bentuk pengawasan yang terdapat dalam teori-teori pengawasan, yaitu di antaranya: ${ }^{13}$

1. Ditinjau dari segi kedudukan badan/organ yang melaksanakan pengawasan, terdiri dari:

a) Pengawasan Internal

Pengawasan internal merupakan pengawasan yang dilakukan oleh satu badan yang secara organisatoris/struktural masih termasuk dalam lingkungan pemerintahan sendiri dalam hal ini karena Bidang Notariat masuk pada lingkungan Departemen Hukum dan Hak Asasi Manusia Republik. Anggota Majelis Pengawas berwenang melakukan pengawasan terhadap para Notaris yang didasarkan pada ketentuan UUJN, Permenkumham Nomor 02/2004 serta Permenkumham Nomor 15/2020 tentang Tata Cara Pemeriksaan Majelis Pengawas Terhadap Notaris, dan juga aturan-aturan lainnya yang terkait.

b) Pengawasan yang dilakukan secara fungsional oleh aparat pengawasan terhadap keuangan negara dan khususnya terhadap perbuatan pemerintahan di bidang friesermessen.

2. Pengawasan Eksternal

Pengawasn eksternal Yakni pengawasan yang dilakukan oleh organ/lembaga secara organisatoris/ struktural yang berada diluar pemerintah (eksekutif), misalnya dalam pengawasan yang dilakukan oleh organisasi Notaris yaitu Ikatan Notaris Indonesia terhadap para Notaris.

3. Pengawasan Preventif dan Represif

Adapun yang dimaksud pengawasan preventif yaitu pengawasan yang dilakukan sebelum dikeluarkan suatu keputusan/ketetapan pemerintah, yang disebut pengawasan apriori, yang akan ditetapkan dengan peraturan pemerintah.

\footnotetext{
${ }^{11}$ Pasal 1 ayat (3) Undang-Undang Dasar Negara Republik Indonesia 1945 (hasil perubahan ketiga), sebelum perubahan ketiga, dalam Undang-Undang Dasar 1945 tidak ditemukan suatu rumusan yang in expressis verbis yang menyebutkan atau merumuskan negara hukum. Hanya penjelasan umum Undang-Undang Dasar 1945 yang menyatakan bahwa Indonesia negara berdasarkan hukum (Rechtstaat) yang diperlawankan dengan machtstaat, setelah perubahan ketiga Undang-Undang Dasar 1945, penjelasan ketiga Undang-Undang Dasar 1945 dihapus dari naskah resmi ketiga Undang-Undang Dasar 1945.

${ }^{12}$ G.H.S. Lumban Tobing, Peraturan Jabatan Notaris, Erlangga, Jakarta, 2003, hlm. 301.

${ }^{13}$ Habib Adjie, Majelis Pengawas Notaris, PT. Refika Aditama, Bandung, 2015, hlm. 101.
} 
Pengawasan represif, yaitu pengawasan yang dilakukan sesudah dikeluarkannya keputusan/ketetapan pemerintah, sehingga bersifat korektif dan memulihkan suatu tindakan yang keliru, disebut juga pengawasan aposteriori.

4. Pengawasan dari segi hukum

Pengawasan dari segi hukum merupakan suatu penilaian tentang sah atau tidaknya suatu akta yang telah dibuat oleh Notaris yang menimbulkan akibat hukum.

Namun dalam pelaksanaannya pengawasan, pemeriksaan, dan pemberian sanksi terhadap Notaris juga ditemukan kendala. Fokus dalam pembahasan ini adalah menganalisa kendala-kendala tersebut pasca terbitnya Permenkumham Nomor 15/2020. Peraturan menteri a quo memberikan kewenangan kepada Majelis Pemeriksa untuk memberikan sanksi terhadap Notaris. Hal tersebut merupakan suatu kekeliruan sebab berdasarkan ketentuan yang lebih tinggi, yakni UUJN tidak mengatur atau memberikan kewenangan terhadap Majelis Pemeriksa untuk memberikan sanksi terhadap Notaris. Fungsi dari Majelis Pemeriksa seharusnya tetap sesuai amanat dalam aturan-aturan sebelumnya sehingga tidak terjadi tumpang tindih kewenangan antara Majelis Pemeriksa dan Majelis Pengawas. Saat ini dalam praktiknya, pernah terjadi Majelis Pemeriksa menanyakan kepada Majelis Pengawas Wilayah tentang siapa yang sebenarnya mempunyai kewenangan pemberian sanksi bagi Notaris yang terbukti bersalah. Namun dapat diselesaikan dalam rapat bersama anggota MPW dengan Majelis Pemeriksa. Diambil kesepakatan bahwa kewenangan pemberian sanksi tetap ada pada MPW.

\section{Penutup}

Pasal 73 UUJN menentukan bahwa Majelis Pengawas Wilayah yang berwenang menjatuhkan sanksi kepada Notaris dan Pasal 77 UUJN menentukan pula Majelis Pengawas Pusat yang berwenang menjatuhkan sanksi. Namun dalam Permenkumham Nomor 15 Tahun 2020 tersebut menentukan bahwa kewenangan pemberian sanksi kepada Notaris ada pada Majelis Pemeriksa. Permenkumham Nomor 15 Tahun 2020 bertentangan dengan UUJN dan terkesan ada tumpang tindih aturan, semestinya permenkumham tidak bisa men-downgrade atau mengubah ketentuan dalam UUJN.

Pelaksanaan Pasal 1 angka 4 Permenkumham Nomor 15 Tahun 2020 sulit diterapkan sebab berdasarkan ketentuan yang lebih tinggi, yakni UUJN tidak mengatur atau memberikan kewenangan terhadap Majelis Pemeriksa untuk memberikan sanksi terhadap Notaris. Fungsi dari Majelis Pemeriksa seharusnya tetap sesuai amanat dalam aturan-aturan sebelumnya sehingga tidak terjadi tumpang tindih kewenangan antara Majelis Pemeriksa dan Majelis Pengawas. Namun dapat diselesaikan dalam rapat bersama anggota Majelis Pengawas Wilayah dengan Majelis Pemeriksa dan diambil kesepakatan bahwa kewenangan pemberian sanksi tetap ada pada Majelis Pengawas Wilayah.

Dalam hal pemberian sanksi bagi Notaris seharusnya hanya Majelis Pengawas Notaris saja yang diberikan kewenangan, demi terciptanya suatu kepastian hukum terhadap pengawasan Notaris. Diharapkan keberadaan Majelis Pemeriksa selaku badan yang dibentuk oleh Majelis Pengawas Notaris dapat melakukan pemeriksaan terhadap Notaris dengan tetap bersinergi dengan Majelis Pengawas sehingga tujuan dari 
pemeriksaan dan pengawasan Notaris dapat berjalan secara maksimal tanpa kendala serta komitmen untuk meluangkan waktu untuk menjalankan tugas masing-masing sebagai anggota Majelis Pengawas sangatlah diperlukan. Juga apabila dalam perkembangan saat ini keberadaan UUJN dianggap sudah tidak sesuai dengan perkembangan atau kebutuhan, alangkah lebih baik UUJN itu sendiri yang diamandemen, bukan menerbitkan permenkumham.

\section{Daftar Pustaka}

\section{Buku}

Adjie, Habib, Sanksi Perdata dan Administratif Terhadap Notaris Sebagai Pejabat Publik, Bandung, Refika Aditama, 2009.

Luthfan Hadi Darus, Muhammad, Hukum Notariat dan Tanggungjawab Jabatan Notaris, Cetakan Pertama, Yogyakarta, UII Press, 2017.

M. Hadjon, Philipus, Formulir Pendaftaran Tanah Bukan Akta Otentik, Surabaya, Surabaya Post, 2001.

Pandoman, Agus, Teori dan Praktik Akta; Perikatan Publisitas dan Non-Publisitas, Cetakan Pertama, Yogyakarta, PT. Raga Utama Kreasi, 2017.

Sulihandari, Hartanti dan Rifiani, Nisya, Prinsip-Prinsip Dasar Profesi Notaris, Jakarta, Dunia Cerdas, 2013.

Soerodjo, Irawan, Kepastian Hukum Hak Atas Tanah di Indonesia, Surabaya, Arkola, 2003.

Whitecross Patton, George, A Text-Book of Jurisprudence, Oxford, Clarendon Press, 1953.

\section{Peraturan Perundang-Undangan}

Kitab Undang-Undang Hukum Perdata, Balai Pustaka, 2009.

Undang-Undang Nomor 5 Tahun 1986 tentang Peradilan Tata Usaha Negara.

Undang-Undang Nomor 10 Tahun 1998 tentang Perubahan Atas Undang-Undang Nomor 7 Tahun 1992 tentang Perbankan.

Undang-Undang Nomor 2 Tahun 2014 tentang Perubahan Atas Undang-Undang Nomor 30 Tahun 2004 tentang Jabatan Notaris.

Peraturan Menteri Hukum dan Hak Asasi Manusia Nomor M.02.PR.08.10 Tahun 2004tentang Tata Cara Pengangkatan Anggota, Pemberhentian Anggota, Susunan Organisasi, Tata Kerja dan Tata Cara Pemeriksaan Majelis Pengawas Notaris.

Kode Etik Ikatan Notaris Indonesia. 